\title{
Optimization of Processing Conditions of Akara Egbe from Cowpea Substituted with Bambara Groundnut
}

\author{
Ajetunmobi-Adeyeye Rukayat Ibiwumi ${ }^{1}$, Olajide John Oluranti, ${ }^{1,}$, Alade Abass Olanrewaju ${ }^{2}$ \\ ${ }^{1}$ Department of Food Engineering, Ladoke Akintola University of Technology, Faculty of Engineering and Technology, Ogbomoso, Nigeria \\ ${ }^{2}$ Department of Chemical Engineering, Ladoke Akintola University of Technology, Faculty of Engineering and Technology, Ogbomoso, \\ Nigeria
}

Email address:

joolajide@lautech.edu.ng (O. J. Oluranti)

${ }^{*}$ Corresponding author

\section{To cite this article:}

Ajetunmobi-Adeyeye Rukayat Ibiwumi, Olajide John Oluranti, Alade Abass Olanrewaju. Optimization of Processing Conditions of $A$ kara Egbe from Cowpea Substituted with Bambara Groundnut. International Journal of Food Science and Biotechnology.

Vol. 6, No. 2, 2021, pp. 45-52. doi: 10.11648/j.ijfsb.20210602.14

Received: October 2, 2020; Accepted: October 28, 2020; Published: June 21, 2021

\begin{abstract}
The effects of Bambara groundnut (BGN) substitution and optimization of the deep fat frying processes of $A$ kara Egbe was investigated in this study. Akara Egbe was prepared from paste formulated from flour mixture ratios of BG (20\%$40 \%)$ in black-eye cowpea (BEC), frying temperature $\left(145^{\circ} \mathrm{C}-190^{\circ} \mathrm{C}\right)$ and time $(3-10$ minutes) generated using Box - Behnken experimental design. The moisture content, oil content, crispness and colour difference were considered as responses. Optimum conditions obtained for akara egbe substituted with BG was at frying temperature of $190^{\circ} \mathrm{C}$, frying time 8.5 minutes and $20 \%$ bambara groundnut which gave moisture content of $4.84 \%, 9.76 \%$ oil content, $343.81 \mathrm{~N}$ crispness and 15.43 colour. The polynomial regression models were validated with statistical tool whose values of coefficients of determination $\left(\mathrm{R}^{2}\right)$ ) were $0.9663,0.9161,1.000$ and 0.9988 for moisture content, oil content, breaking force and colour difference, respectively. A significant value $(p<0.05)$ were obtained for moisture content, oil content, breaking force and colour difference when akara egbe was substituted with BG correlated with frying temperature and time.
\end{abstract}

Keywords: Akara egbe, Bambara Groundnut, Cowpea, Deep- fat Frying, Optimum Processing Conditions

\section{Introduction}

There is a great burden on cowpea utilization being the commonest legume consumed in one form or the other in Nigeria and other African countries. However, there are wide varieties of underutilized legumes such as bambara groundnut that could find useful application in the production of akara egbe. The quality of akara egbe vary from one processor to the other due to lack of standardization of the processing conditions and ingredients formulation. Cowpea (Vigna unguiculata) is the most commonly consumed legume in Africa countries particularly in Nigeria and it is an important source of plant protein in human diets. It is high in protein content $(25 \%)$, fiber, B-vitamins and other nutrients (calcium, magnesium, iron, potassium and zinc) [1]. About $80 \%$ of the world production of cowpea is produced in West Africa where it is eaten on a daily basis as foods and food products like bean soup (gbegiri),(moin-moin) steamed cowpea paste and (akara) fried cowpea paste [2].

Bambara groundnut (Vigna subterranean var spontanea) is an indigenous African grain legume and is one of the more important crops grown on the African continent [3]. It is readily available but under-utilized and not well promoted in the local or international markets [4]. It is a good source of protein, carbohydrates, fats and minerals [5].

Akara egbe, which is also referred to as akara Ogbomoso, derived its name from its main centre of production, Ogbomoso, an ancient town in Oyo State, Nigeria. It differs from the conventional akara in terms of processing, product characteristics and shelf stability [6]. Akara egbe is a fried snack mainly eaten as snacks, withwater, cereal porridge or soaked garri. In addition, it can be made by incorporation of underutilized crops such as Bambara nut, pigeon pea to improve the nutritive quality and minimize the cost of production [7]. 
Frying is a unit operation which involve heat and mass transfer, resulting in physical, chemical, nutritional and sensory changes (texture, colour, taste) [8]. Deep-fat frying is a process which involves submerging a food in extremely hot oil until it reaches a safe minimum internal temperature or cooking of food by immersion in edible oil or fat at a temperature higher than the boiling point of water [9]. It is high temperature and a short time process which involves both mass and heat transfer (mainly represented by water loss and oil uptake) [10]. Also, it is a fast cooking method that can be used to impart cooking, enrich, contribute energy and aftermouth feel to finished product such as fried chicken, French fries, akara egbe and potato chips [11]. It is a rapid, low-cost process for drying, cooking and producing products with useful sensory attributes. When the food is deep-fried properly, it will be hot and crispy on the outside, cooked safely in the centre and destroy bacteria.

Optimization is a method used to improve the performance of a system and to increase yield without increasing the cost. It additionally comprises of a group of techniques utilized in the empirical study of connections between at least one quantified reactions (dependent variables) and number of info variables (independent variables). A significant procedure in optimization is Response Surface Methodology (RSM). Most published studies on akara egbe over the years have deal primarily with final product quality [6] and none of these reports have particularly optimized frying conditions to obtain fried akara egbe of acceptable quality attributes. However, there is little or no published work on statistical approach in RSM during DFF of akara egbe experiment for obtaining optimum conditions for quality characteristics of akara egbe.

Therefore the aim of this research work was to investigate the effects of bambara groundnut substitution and optimized the deep fat frying process for the production of akara egbe.

\section{Methodology}

Materials

The black-eye cowpea and Bambara groundnut were obtained locally from Sabo market, Ogbomoso, Nigeria. They were identified in the Department of Crop Production and Soil Science, Ladoke Akintola University of Technology, Ogbomoso, Nigeria. The refined bleached deodorized vegetable oil, salt, low-density polythene bags were purchased from the same market. The deep fat fryer, corn milling machine, stainless steel knives, plastic bowls, aluminium plastic sieves, and trays were obtained from Food Processing Laboratory, Department of Food Science and Engineering, Ladoke Akintola University of Technology, Ogbomoso.

Methods

The black-eye cowpea and bambara groundnut (Vigna subterranea var. spontanea) were sorted to remove extraneous material. They were both processed separately to produce flour. Parts of the cowpea flour were substituted with $20 \%, 30 \%$ and $40 \%$ BG by weight (136 g) to produce paste with the addition of $40 \mathrm{ml}$ of water, other ingredients and fried to produce akara egbe.

\subsection{Production of Cowpea Flour}

The cowpea seeds were cleaned by hand-picking chaffs, stalks and stones. Cowpea flour was produced according to the method of [6]. Clean cowpea seeds were soaked in cleaned water for $5 \mathrm{~min}$ for conditioning, and easy removal of the seed coat. The conditioned seeds were dehulled manually and allowed to drain, and then dried at $50{ }^{\circ} \mathrm{C}$ in a forced draught oven for $24 \mathrm{~h}$. The dried cotyledon was drymilled in an attrition mill and sieved to obtain flour with a particle size in the range $45-150 \mu \mathrm{m}$ uniform particle sizes.

Production of Bambara groundnut flour

Bambara groundnut flour was produced according to the method of Olanipekun et al., [7] with modification. Bambara groundnut seeds were cleaned by hand-picking chaffs, stalk and stones. The cleaned seeds were soaked in $0.5 \%$ sodium hydrogen carbonate $\left(\mathrm{NaHCO}_{3}\right)$ solution at a ratio $1: 2$ for $4 \mathrm{~h}$. The conditioned seeds were decorticated and allowed to drain, and then dried at $45^{\circ} \mathrm{C}$ in a cabinet dryer for $24 \mathrm{~h}$. The dried cotyledon was dry-milled in an attrition mill and sieved to obtain flour with particle size in the range $45-150 \mu \mathrm{m}$.

\subsection{Laboratory Preparation of Akara Egbe}

The preparation of akara egbe was carried out in the laboratory following under stringent hygienic conditions according to the modified method of $[6,12]$. Cowpea and Bambara nut flours were weighed and mixed according to the experimental design. To $136 \mathrm{~g}$ of each of the flour mixtures, $30 \mathrm{~g}$ of common salt and $40 \mathrm{ml}$ of water was added, and stirred to form stiff pastes based on preliminary study and literatures. Flat sheets of the paste was formed, and cut into discs of cylindrical form. These were then deep-fried in vegetable oil in two quick successions to produce a reddish brown, hard textured and low moisture produce at a temperature $\left(145-190^{\circ} \mathrm{C}\right)$ and time $(3-5 \mathrm{~min})$. It was cooled for $20 \mathrm{~min}$ before the final deep fat frying at the same temperature and time (5-10 min). The akara egbe pieces was drained, cooled and packaged in low-density polyethylene.

\subsection{Experimental Design for Optimization of Process Parameters on Traditional Akara Egbe}

Box-Behnken design of Response Surface Methodology (RSM) was used to study the effects of the independent variables on the quality attributes of akaraegbe. The three independent variables chosen were: frying temperature $\left(\mathrm{X}_{1}\right)$, frying time $\left(\mathrm{X}_{2}\right)$ and $\% \mathrm{BGF}$ in the flour blend $\left(\mathrm{X}_{3}\right)$ while the dependent variables (responses) were: colour, crispness, moisture content and oil content. The levels of each variable were established based on a series of preliminary experiments and coded as $-1,0$, and 1 resulting in a total of 17 experimental runs to investigate the effect of these process variables on the responses and $100 \%$ cowpea at temperature for $170^{\circ} \mathrm{C}$ for 8 mins served as control. The statistical analysis of the experimental design was carried out using Design Expert Version 6.0.2 (Stat Ease Inc., Minneapolis, MN, USA).

The dependent and independent variables was represented 
mathematically using a second order polynomial equation (Equation 1).

$$
\begin{aligned}
& Y=\beta_{0}+\beta_{1} X_{1}+\beta_{2} X_{2}+\beta_{3} X_{3}+\beta_{11} X_{1}^{2}+\beta_{22} X_{2}^{2}+\beta_{33} X_{3}^{2}+\beta_{12} X_{1} X_{2}+\beta_{13} \\
& \mathrm{X}_{1} \mathrm{X}_{3}+\beta_{23} \mathrm{X}_{2} \mathrm{X}_{3} \ldots \ldots
\end{aligned}
$$

where, $Y$ is predicted responses (moisture content, oil content, colour and crispness). The $X_{1}-X_{3}$ are coded independent variables (time, temperature and $\%$ Bambara groundnut) and $\beta_{0}, \beta_{1}-\beta_{3}, \beta_{11}-\beta_{33}$ and $\beta_{12}-\beta_{23}$ are the regression coefficients for intercept, linear, quadratic and interaction effects respectively.

\subsection{Analytical Procedures}

\subsubsection{Moisture Content}

Moisture content of the samples was determined using standard gravimetric method (Equation (2)). A sample of $3 \mathrm{~g}$ was weighed into a pre-weighed clean dried dish, after which the dish was placed in a well-ventilated oven (draft air Fisher Scientific Isotemp $\mathrm{R}$ Oven model 655F) maintained at $103 \pm 2^{\circ} \mathrm{C}$ for $24 \mathrm{~h}$ until a constant weight was obtained. The lost in weight was recorded as moisture [13].

$$
\% \text { Moisture content }=\frac{M_{1}-M 2}{M 1-M 0} \times 100 \%
$$

Where $M_{o}=$ weight in $\mathrm{g}$ of dish $M_{1}=$ Weight in $\mathrm{g}$ of dish and sample before drying

$M_{2}=$ Weight in $\mathrm{g}$ of dish and sample after drying. Note $M_{1}-M_{0}=$ weight of sample prepared for drying.

\subsubsection{Oil Content}

Oil content of the sample was determined according to [13]. The fried samples was grinded in porcelain mortar and pestle after drying the samples in an oven (draft air Fisher Scientific Isotemp R Oven model 655F) at temperature of $60 \pm 2^{\circ} \mathrm{C}$ for $2 \mathrm{~h}$ after each frying experiment. Crude fat was extracted from $3 \mathrm{~g}$ of the sample with hexane using a fat extractor (Soxtec System HT2 fat extractor), and the solvent evaporated off to get the fat. The difference between the initial and final weight of the extraction cup was recorded as the crude fat content. The oil content of the sample was represented by the crude fat content obtained (Equation 3.3).

$$
\% \mathrm{Fat}=\frac{(A)-(B)}{C} \times 100 \%
$$

$\mathrm{A}=$ wt of flask + fat $\mathrm{B}=$ wt of sample after drying $\mathrm{C}=$ weight of sample

\subsubsection{Breaking Force}

The breaking force of the akaraegbe was determined using a universal testing machine (model M500, Testometric AX, Rochdale, Lancashire, England) equipped with a $50 \mathrm{~mm} / \mathrm{min}$ load cell. Akara egbe of uniform sizes were selected and then placed on a metal support with jaws at a distance of about 25 $\mathrm{mm}$. They were pressed in the middle with a cylindrical flat end plunger (64 mm diameter) at a speed of $50 \mathrm{~mm} / \mathrm{min}$. The measurement was recorded by a computer connected directly to the equipment. The breaking force $(\mathrm{N})$ interpreted as crispness was obtained as the peak force from the forcedeformation curve [9].

2.4.4. Colour

The colorimeter operates like digital camera in which the pictures of akara egbe was taken and placed in a probe covered with a black plastic cover. The picture taken is displayed on an LCD screen with the readings for the $\mathrm{L}^{*}$ (lightness), $\mathrm{a} *$ (redness), $\mathrm{b} *$ (yellowness) and $\Delta \mathrm{E}$ (colour difference) as described by [9]. Colour difference $(\Delta \mathrm{E})$ was calculated according to the equation:

$$
\Delta \mathrm{E}=\left[\left(L-L_{0}\right)+\left(a-a_{0}\right)+\left(b-b_{0}\right)\right]^{1 / 2}
$$

Where $\mathrm{L}_{0}, \mathrm{a}_{0}$ and $\mathrm{b}_{0}$ were the lightness $(L)$, redness $(a)$ and yellowness (b) value of akara egbe from cowpea substituted with bambara groundnut which were used as references. $\Delta \mathrm{E}=$ Colour difference Hunter.

\subsection{Statistical Analysis}

All the experimental procedures were repeated three times andmean values recorded as measured data. Collected data was processed using a commercial statistical package, DesignExpert Version 6.0.8 (StateaseInc; Minneapolis USA, version) and sensory evaluation data was analyzed with SPSS version 20 (SPSS Inc., Chicago, IL) using analysis of variance and the means was separated using Duncan Multiple Range Test.

The Design experts software was used for analysis of variance, mathematical modelling, regression analysis, and optimization. The response surface plots were generatedfor different interactions. The significance of the equation parameters for each dependent variable was assessed by Ftest and $\mathrm{P}$ value $<0.05$.

\subsection{Optimization and Validation}

The procedure was based on the hypothesis that quality attributes (moisture and oil contents, crispness and colour parameters) were functionally related to frying temperature, frying time and substitution of $\%$ Bambara nut and attempts were made to fit multiple regression equations describing the responses. Range-finding experimentswere performed at the outset of this work in order to ascertain what frying conditions, frying time and substitution of $\%$ Bambara nut could be applied to the akara egbe so that the product would be acceptable to consumers on the basis of sensory properties. The suitability of the model used for predicting the optimum conditions for akara egbe production was tested by comparing the experimental and predicted values obtained. Standard deviations were calculated for each of the parameters. 


\section{Results and Discussion}

Table 1. Experimental design arrangement for process variables and selected properties (responses) for production of akara egbe substituted with Bambara groundnut.

\begin{tabular}{llllllll}
\hline Runs & Time (min) & Temp $^{\circ} \mathrm{C}$ & $\mathbf{B g}(\mathbf{\%})$ & $\mathbf{M C ~ ( \% )}$ & $\mathbf{O C}(\mathbf{\%})$ & $\mathbf{B F}(\mathbf{N})$ & $\Delta \mathbf{E}$ \\
\hline 1 & 10 & 190 & 30 & $5.23 \pm 0.05^{\mathrm{a}}$ & $11.97 \pm 0.02^{\mathrm{b}}$ & $422 \pm 300.25^{\mathrm{a}}$ & $10.78 \pm 4.91^{\mathrm{c}}$ \\
2 & 3 & 167.5 & 20 & $6.35 \pm 0.06^{\mathrm{bc}}$ & $14.93 \pm 0.04^{\text {def }}$ & $228 \pm 81.83^{\mathrm{a}}$ & $26.08 \pm 2.98^{\mathrm{g}}$ \\
3 & 3 & 190 & 30 & $8.17 \pm 0.04^{\mathrm{e}}$ & $16.06 \pm 0.04^{\mathrm{h}}$ & $377 \pm 227.21^{\mathrm{a}}$ & $16.74 \pm 2.38^{\mathrm{e}}$ \\
4 & 6.5 & 167.5 & 30 & $6.16 \pm 0.07^{\mathrm{b}}$ & $14.70 \pm 0.50^{\text {cdef }}$ & $1050 \pm 348.04^{\mathrm{a}}$ & $13.90 \pm 0.18^{\mathrm{d}}$ \\
5 & 10 & 145 & 30 & $6.19 \pm 0.07^{\mathrm{b}}$ & $15.80 \pm 0.39^{\text {gh }}$ & $1220 \pm 82.94^{\mathrm{a}}$ & $7.67 \pm 0.38^{\mathrm{b}}$ \\
6 & 6.5 & 167.5 & 30 & $6.16 \pm 0.07^{\mathrm{b}}$ & $14.70 \pm 0.50^{\text {cdef }}$ & $1050 \pm 348.04^{\mathrm{a}}$ & $13.90 \pm 0.18^{\mathrm{d}}$ \\
7 & 6.5 & 145 & 20 & $6.64 \pm 0.36^{\mathrm{d}}$ & $15.28 \pm 0.02^{\mathrm{fg}}$ & $2700 \pm 1849.17^{\mathrm{b}}$ & $7.92 \pm 0.02^{\mathrm{b}}$ \\
8 & 6.5 & 145 & 40 & $6.41 \pm 0.03^{\mathrm{c}}$ & $14.17 \pm 0.01^{\text {cd }}$ & $1170 \pm 688.65^{\mathrm{a}}$ & $13.64 \pm 0.19^{\mathrm{d}}$ \\
9 & 10 & 167.5 & 40 & $5.00 \pm 0.06^{\mathrm{a}}$ & $10.60 \pm 0.20^{\mathrm{a}}$ & $429 \pm 83.24^{\mathrm{a}}$ & $3.35 \pm 0.06^{\mathrm{a}}$ \\
10 & 3 & 167.5 & 40 & $8.32 \pm 0.20^{\mathrm{e}}$ & $14.49 \pm 0.20^{\text {cde }}$ & $367 \pm 366.87^{\mathrm{a}}$ & $12.35 \pm 0.20^{\text {cd }}$ \\
11 & 6.5 & 167.5 & 30 & $6.16 \pm 0.07^{\mathrm{b}}$ & $14.70 \pm 0.50^{\text {cdef }}$ & $1050 \pm 348.04^{\mathrm{a}}$ & $13.90 \pm 0.18^{\mathrm{d}}$ \\
12 & 3 & 145 & 30 & $8.11 \pm 0.27^{\mathrm{e}}$ & $15.02 \pm 0.89^{\text {ef }}$ & $106 \pm 24.32^{\mathrm{a}}$ & $31.17 \pm 0.76^{\mathrm{h}}$ \\
13 & 6.5 & 167.5 & 30 & $6.16 \pm 0.07^{\mathrm{b}}$ & $14.70 \pm 0.50^{\text {cdef }}$ & $1050 \pm 348.04^{\mathrm{a}}$ & $13.90 \pm 0.18^{\mathrm{d}}$ \\
14 & 6.5 & 190 & 20 & $5.10 \pm 0.05^{\mathrm{a}}$ & $11.02 \pm 0.47^{\mathrm{a}}$ & $612 \pm 401.30 \mathrm{a}$ & $2.79 \pm 0.22^{\mathrm{a}}$ \\
15 & 6.5 & 190 & 40 & $6.27 \pm 0.08^{\mathrm{bc}}$ & $14.91 \pm 0.43^{\text {def }}$ & $395 \pm 239.23^{\mathrm{a}}$ & $12.72 \pm 0.01^{\text {cd }}$ \\
17 & 10 & 167.5 & 20 & $5.20 \pm 00.15^{\mathrm{a}}$ & $11.96 \pm 0.52^{\mathrm{b}}$ & $775 \pm 846.82^{\mathrm{a}}$ & $4.46 \pm 0.06^{\mathrm{a}}$ \\
18 & 6.5 & 167.5 & 30 & $6.16 \pm 0.07^{\mathrm{b}}$ & $14.70 \pm 0.50^{\text {cdef }}$ & $1050 \pm 348.04^{\mathrm{a}}$ & $13.90 \pm 0.18^{\mathrm{d}}$ \\
\hline
\end{tabular}

${ }^{\mathrm{a}-\mathrm{h}}$ means with the same letter on the same column are not significantly different $(\mathrm{P}<0.05)$.

Where; $\mathrm{OC}=\mathrm{Oil}$ content, $\mathrm{MC}=$ Moisture content, $\mathrm{BF}=$ Breaking force, $\Delta \mathrm{E}=$ Colour difference.

Response surface analysis of variables and responses

Table 1 showed the results of response surface analysis of the variation of moisture content (MC), oil content (OC), breaking force $(\mathrm{BF})$ and colour

$(\Delta \mathrm{E})$ with frying temperature, frying timefor the production of akara egbe from cowpea (control) and that of cowpea substituted with bambara groundnut. The standard errors calculated were also shown for the responses in which same letter on the same column are not significantly differe.

Table 2. Coefficients of regression of generated model.

\begin{tabular}{lllll}
\hline Coefficients & $\boldsymbol{R}_{\boldsymbol{1}}$ & $\boldsymbol{R}_{\boldsymbol{2}}$ & $\boldsymbol{R}_{\mathbf{3}}$ & $\boldsymbol{R}_{\mathbf{4}}$ \\
\hline$B_{0}$ & 6.23 & 14.28 & 753.91 & $2.251 \mathrm{E}+6$ \\
$\beta_{1}$ & $-0.322^{*}$ & $-0.5993^{*}$ & $-329.88^{*}$ & $3.405 \mathrm{E}+6^{*}$ \\
$\beta_{2}$ & $-1.17^{*}$ & $-0.6123^{*}$ & $152.25^{*}$ & $3.472 \mathrm{E}+6^{*}$ \\
$\beta_{3}$ & 0.2773 & $0.8463^{*}$ & $51.25^{*}$ & $3.772 \mathrm{E}+5^{*}$ \\
$\beta_{11}$ & 0.368 & - & $166.38^{*}$ & $2.60 \mathrm{E}+5^{*}$ \\
$\beta_{22}$ & $0.3733^{*}$ & & $-550.12^{*}$ & $1.95 \mathrm{E}+6^{*}$ \\
$\beta_{33}$ & -0.3158 & & $-50.12^{*}$ & $4.22 \mathrm{E}+5^{*}$ \\
$\beta_{12}$ & -0.2550 & $-1.22^{*}$ & $-404.75^{*}$ & $6.30 \mathrm{E}+5^{*}$ \\
$\beta_{13}$ & $0.3500^{*}$ & $1.63^{*}$ & $-57.50^{*}$ & $3.40 \mathrm{E}+6^{*}$ \\
$\beta_{23}$ & $-0.5425^{*}$ & 1.09 & $-121.25^{*}$ & $1.06 \mathrm{E}+5^{*}$ \\
F value & 22.28 & 14.56 & $3.27 \mathrm{E}+5$ & 374.14 \\
P value & 0.0002 & 0.0006 & $<0.0001$ & $<0.0001$ \\
$\mathrm{R}^{2}$ & 0.9663 & 0.9161 & 0.9997 & 0.9988 \\
\hline
\end{tabular}

Note: ${ }^{*} P<0.05$. Where, $\mathrm{R}_{1}=$ Moisture content $(\%), \mathrm{R}_{2}=$ Oil content $(\%)$, $\mathrm{R}_{3}=$ Breaking force $(\mathrm{N}), \mathrm{R}_{4}=$ Colour.

$$
\begin{gathered}
\mathrm{MC}=6.23-0.3225 \mathrm{X}_{1}-1.1700 \mathrm{X}_{2}+0.2733 \mathrm{X}_{3}-0.2550 \mathrm{X}_{1} \mathrm{X}_{2}+0.3500 \mathrm{X}_{1} \mathrm{X}_{3}-0.5425 \mathrm{X}_{2} \mathrm{X}_{3}+0.328 \mathrm{X}_{1}{ }^{2}+0.3733 \mathrm{X}_{1}{ }^{2}-0.3158 \mathrm{X}_{3}^{2} \\
\mathrm{OC}=14.55-0.5993 \mathrm{X}_{1}-0.6123 \mathrm{X}_{2}+0.8463 \mathrm{X}_{3}-1.22 \mathrm{X}_{1} \mathrm{X}_{2}+1.63 \mathrm{X}_{1} \mathrm{X}_{3}+1.09 \mathrm{X}_{2} \\
\mathrm{BF}=1049.88-329.88 \mathrm{X}_{1}+152.25 \mathrm{X}_{2}-51.25 \mathrm{X}_{3}-404.75 \mathrm{X}_{1} \mathrm{X}_{2}-57.50 \mathrm{X}_{1} \mathrm{X}_{3}-121.25 \mathrm{X}_{2} \mathrm{X}_{3}+166.38 \mathrm{X}_{1}{ }^{2}-550.12 \mathrm{X}_{2}{ }^{2}-50.12 \mathrm{X}_{3}{ }^{2} \\
\Delta \mathrm{E}=2.251 \mathrm{E}+7+3.405 \mathrm{E}+6 \mathrm{X}_{1}+3.472 \mathrm{E}+6 \mathrm{X}_{2}+3.772 \mathrm{E}+5 \mathrm{X}_{3}+6.30 \mathrm{E}+5 \mathrm{X}_{1} \mathrm{X}_{2}+3.40 \mathrm{E}+6 \mathrm{X}_{1} \mathrm{X}_{3}+1.06 \mathrm{E} \\
+5 \mathrm{X}_{2} \mathrm{X}_{3}+2.60 \mathrm{E}+5 \mathrm{X}_{1}{ }^{2}+1.95 \mathrm{E}+6 \mathrm{X}_{2}{ }^{2}+4.22 \mathrm{E}+5 \mathrm{X}_{3}{ }^{2}
\end{gathered}
$$




\subsection{Effect of Variables on the Responses}

\subsubsection{Moisture Content}

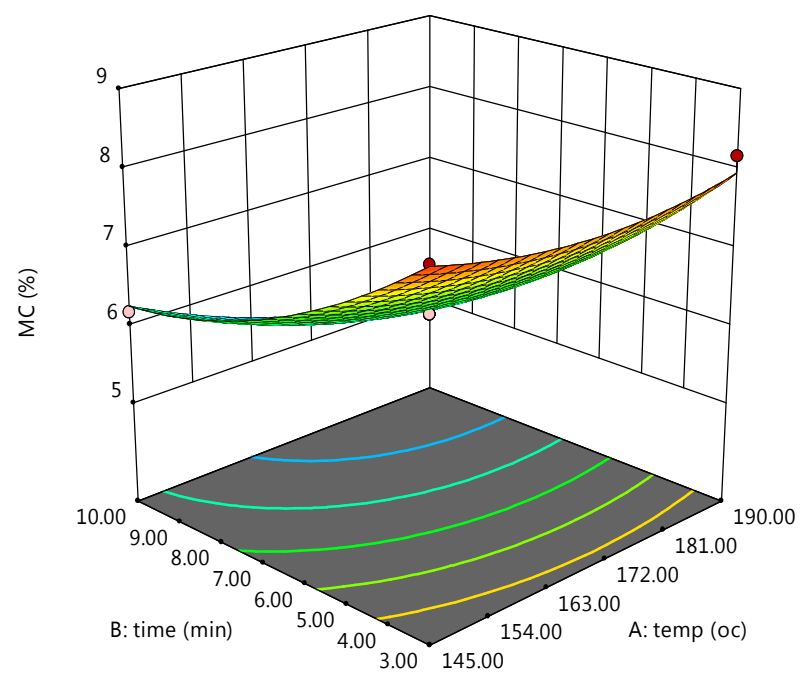

(a)

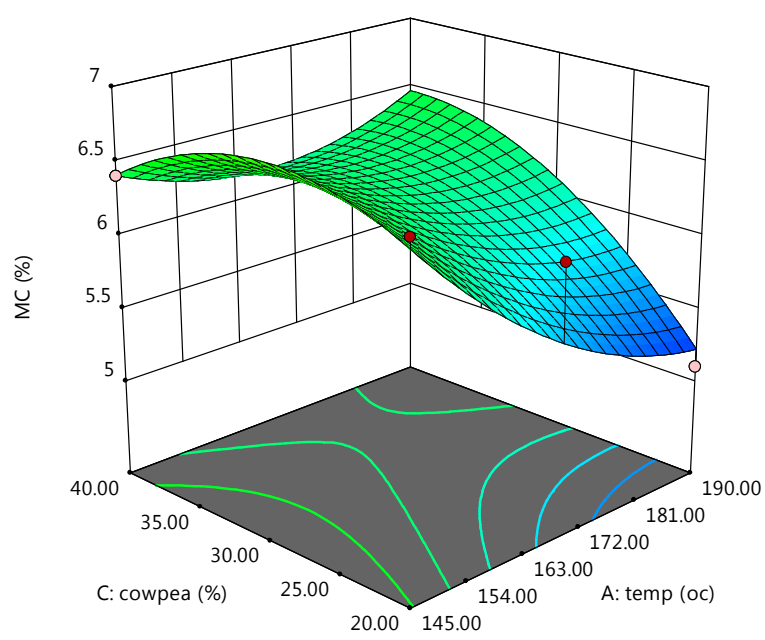

(b)

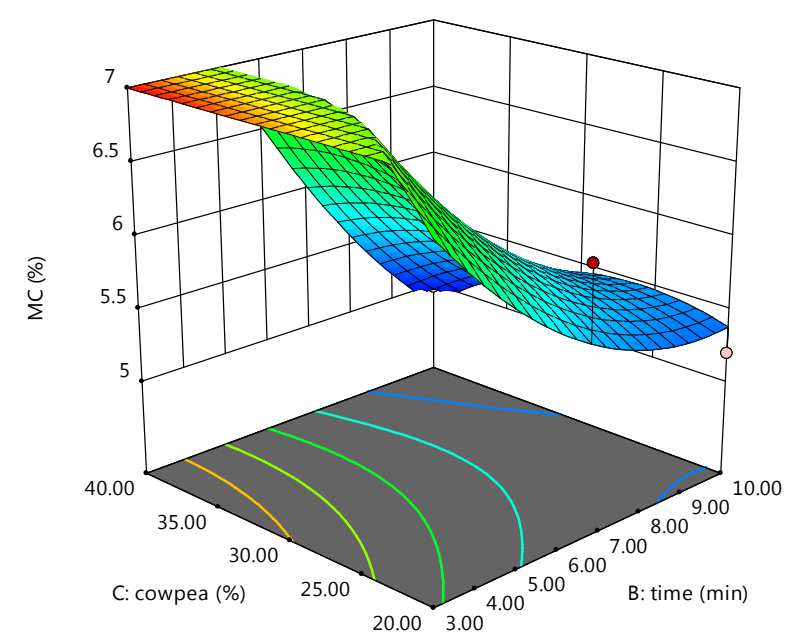

(c)

Figure 1. The surface plot for moisture content of deep fried akaraegbe as affected by frying temperature, frying time and\%Bambara groundnut.
Figure $1 \mathrm{a}-\mathrm{c}$, shows the surface plots of moisture content of akara egbe of $\%$ Bambara groundnut $\left(\mathrm{X}_{3}=0\right)$, frying time $\left(\mathrm{X}_{2}\right)$ and frying temperature $\left(\mathrm{X}_{1}=0\right)$ are held constant respectively. The moisture content decreased with increased temperature $\left(X_{1}\right)$ and time $\left(X_{2}\right)$ of frying and decreased in\% Bambara groundnut flour in the flour blend $\left(X_{3}\right)$ as reported by [14]. A close examination of the surface plots in Figure $1 \mathrm{a}-\mathrm{c}$ showed that at frying temperature of $145-190^{\circ} \mathrm{C}$ for frying time $>6 \mathrm{~min}$ and $30 \%$ Bambara groundnut, the moisture contents is $6 \%$ which is in range with the control i.e. akara egbe produced from cowpea at temperature $170^{\circ} \mathrm{C}$ for $8 \mathrm{~min}$ with moisture content $6.21 \pm 0.03 \%$. and also in range with model result which ranges from $5-8.32 \%$.

At linear level, temperature and timehad negative effect and \% Bambara groundnuthad positive effect on the moisture content. At quadratic level, temperatureand time had positive effect and \% Bambara groundnut had negative effect, while the interactionbetween temperature and time had negative effect, the interactionbetween temperature and\% Bambara groundnut had positive effect and the interactionbetween time and\% Bambara groundnut had negative effect on the moisture content as shown in equation 5. The moisture changes during frying showed the typical progressive decrease with increasing frying time and temperature as reported by [15].

\subsubsection{Oil Content}

Figure $2 \mathrm{a}-\mathrm{c}$, shows the surface plots of oil content of akara egbe of \% Bambara groundnut $\left(\mathrm{X}_{3}=0\right)$, frying time $\left(\mathrm{X}_{2}\right)$ and frying temperature $\left(X_{1}=0\right)$ are held constant respectively. The surface plot showed that as frying temperature and time increased, the oil content of akara egbeis increased (Figure 2a) and a close examination of the surface plots showed that at frying temperature of $145-190^{\circ} \mathrm{C}$ for frying time $>6 \mathrm{~min}$ and $35 \%$ Bambara groundnut, the oil contents is less than $16 \%$ which is in range with oil content gotten from control which was $14.11 \pm 0.02 \%$ and in range with model result which ranges from $11.02-16.06 \%$ and also in agreement with the work of [15] and [16]. However, with increasing temperature $\left(X_{1}\right)$ and increased in time $\left(X_{2}\right)$ of frying and decreased in\% Bambara groundnut flour in the flour blend $\left(X_{3}\right)$, the oil content is increased as shown in Figure 2.

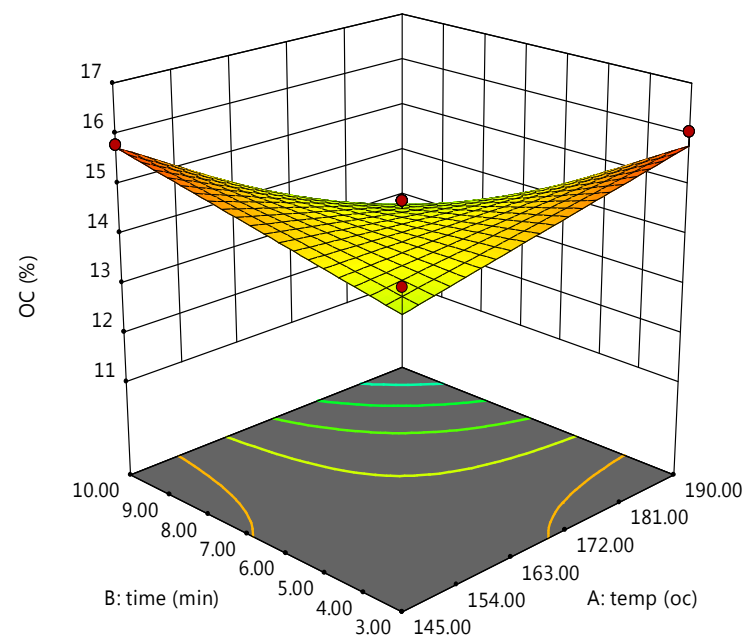

(a) 


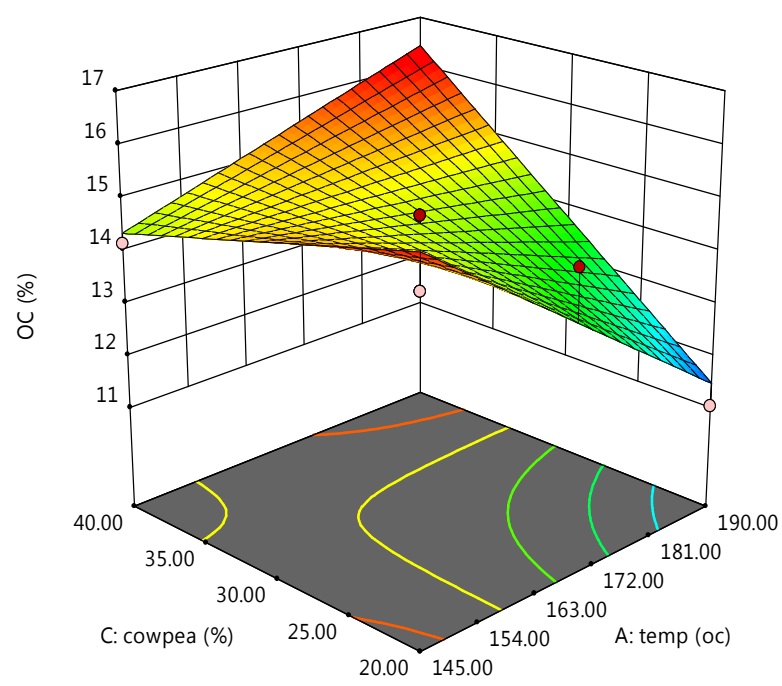

(b)

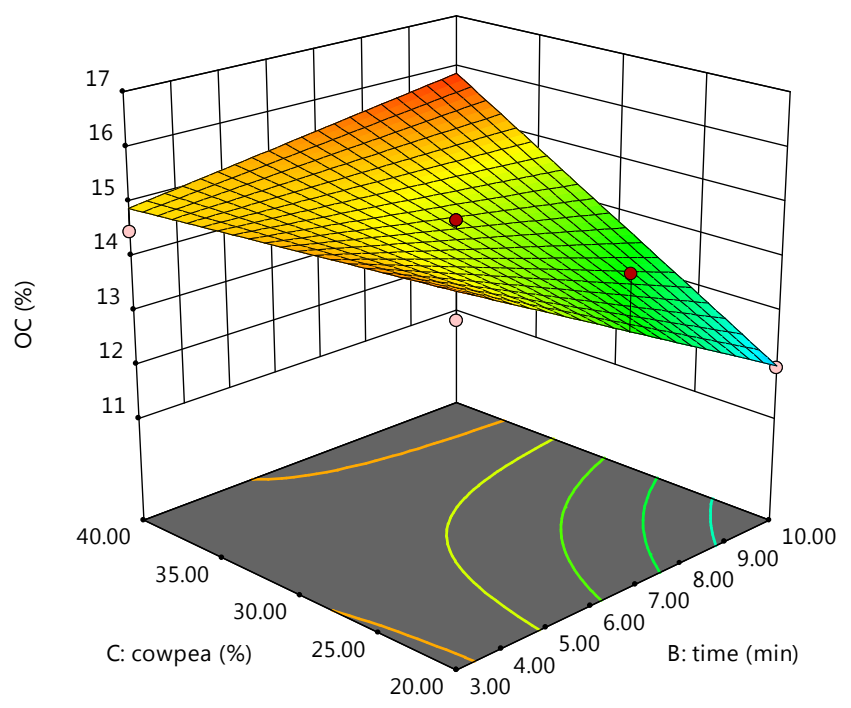

(c)

Figure 2. The surface plot for oil content of deep fried akaraegbe as affected by frying temperature, frying time and\%Bambara groundnut.

In equation 6 , the second order equation for oil content indicates that temperature and timehad negative effect at linear level, and \% Bambara ground nuthad positive effect on the oil content. The variable had no quadratic level while the interactionbetween temperature and time had negative effect, the interaction between temperature and \% Bambara groundnut had positive effect and the interaction between time and \% Bambara groundnut had positive effect on the oil content.

\subsubsection{Breaking Force}

Figure $3 \mathrm{a}-\mathrm{c}$, shows the surface plots of breaking force of akara egbe of frying temperature $\left(\mathrm{X}_{1}=0\right), \%$ Bambara groundnut $\left(\mathrm{X}_{3}=0\right)$, and frying time $\left(\mathrm{X}_{2}\right)$ are held constant respectively. A close examination of the surface plots in Figure 3 a-c showed that at frying temperature of $145-190^{\circ} \mathrm{C}$ for frying time $>6 \mathrm{~min}$ and $40 \%$ Bambara groundnut, the breaking force tends to decrease to less than $1500 \mathrm{~N}$ which is $>240 \pm 177.15 \mathrm{~N}$ the result obtained from the control $(100 \%$ cowpea) and also in range with model result which ranges from 106-1220 N. As frying proceeds, more moisture is being removed from the product thus tending towards crispness this result is in agreement with $[10,9]$.

The second order equation for breaking force as shown in equation 7 indicates that, at linear level, temperature had negative effect, timehad positive effect and $\%$ Bambara groundnuthad negative effect on the breaking force. At quadratic level, temperature had positive effect, time and $\%$ Bambara groundnut had negative effect, while all the interactionhad negative effect on breaking force. The breaking force $(\mathrm{N})$ decreased with the decreased moisture content, decreased in the level of Bambara groundnut substitution which lead to increased in crispness of akara egbe which was probably due to increase in protein and decrease in starch when substituted with Bambara groundnut flour mixture compared with cowpea flour alone, as Bambara groundnut substitution increased in the cowpea- Bambara groundnut mixture, the crispness reduced.

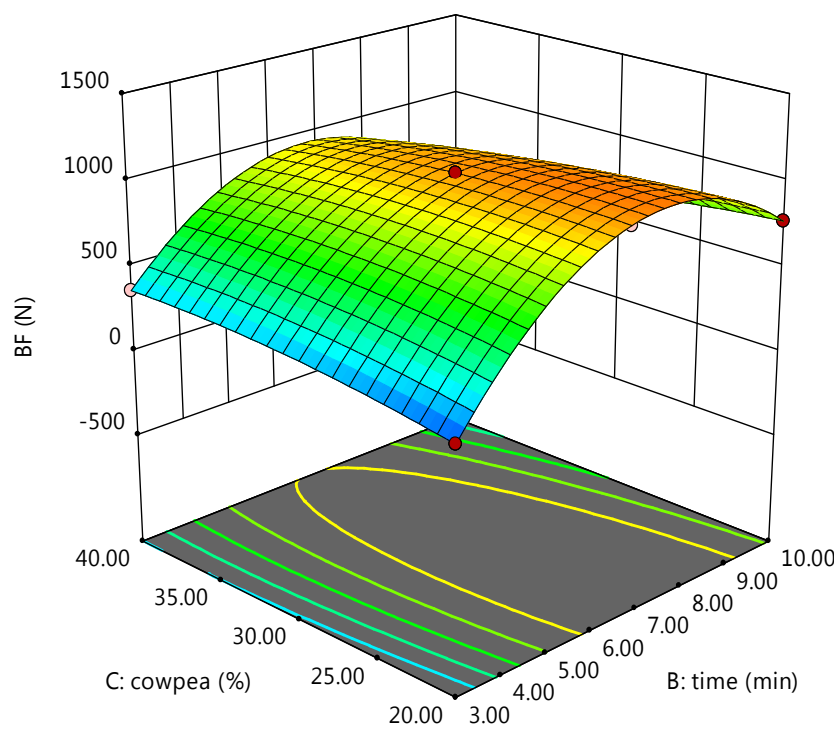

(a)

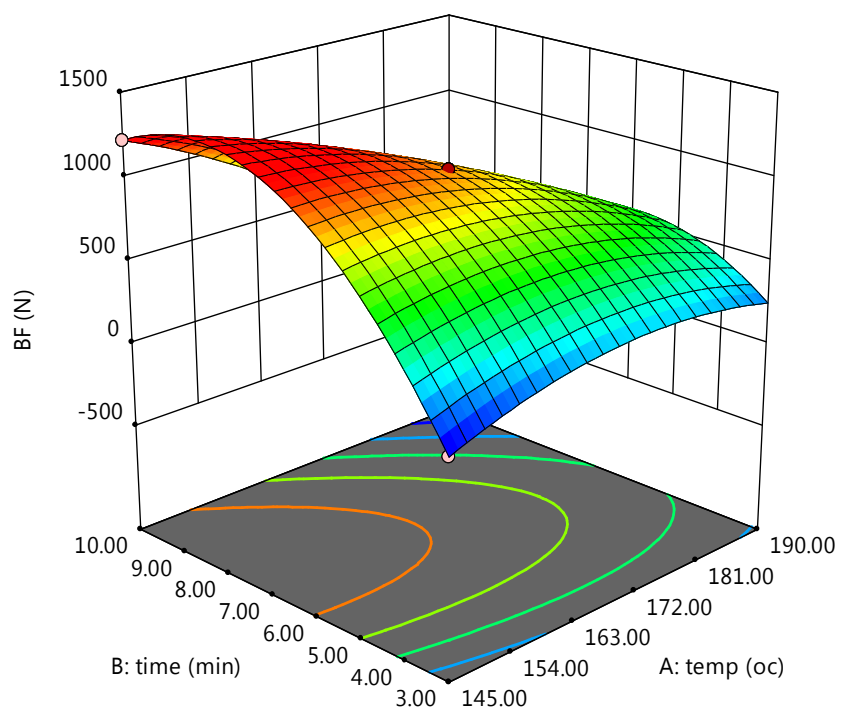

(b) 


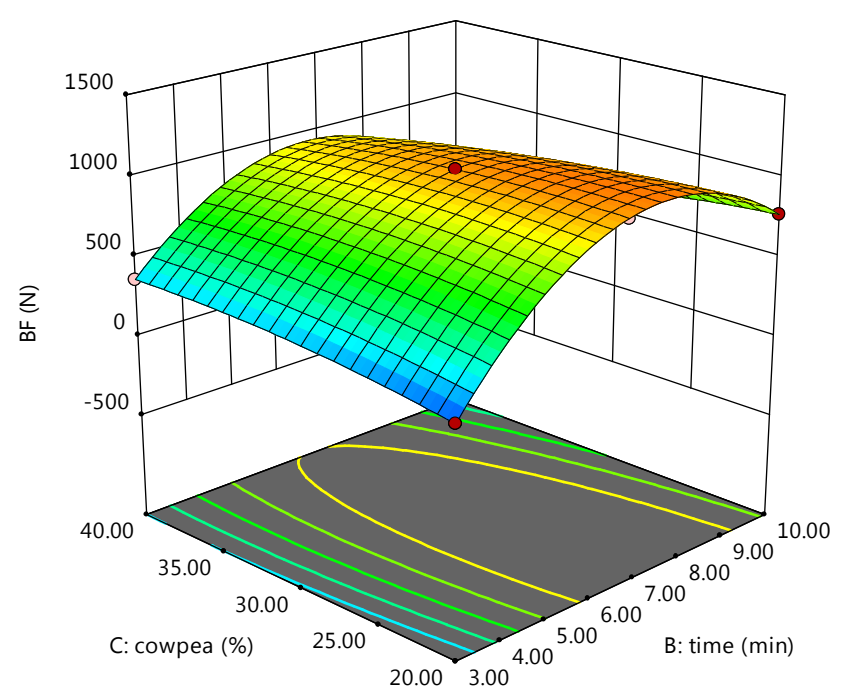

(c)

Figure 3. The surface plot for breaking force of deep fried akara egbe as affected by frying temperature, frying time and\%Bambara groundnut.

\subsubsection{Colour Difference}

Figure $4 \mathrm{a}-\mathrm{c}$, shows the surface plots of colour of akara egbe of $\%$ Bambara groundnut $\left(\mathrm{X}_{3}=0\right)$, frying time $\left(\mathrm{X}_{2}\right)$ and frying temperature $\left(\mathrm{X}_{1}=0\right)$ are held constant respectively. The colour difference decreased with increased temperature $\left(X_{1}\right)$ and time $\left(X_{2}\right)$ of frying and decreased in\% Bambara groundnut flour in the flour blend $\left(X_{3}\right)$ as shown in Figure4 which leads to lower colour quality on the surface of akara egbe. It was ]observed that the increased in temperature led to a significant formation of brown products. A close examination of the surface plots in Figure 4 a-c showed that at frying temperature of $145-190^{\circ} \mathrm{C}$ for frying time $>6 \mathrm{~min}$ and $40 \%$ Bambara groundnut, the change in colour tends to decrease to less than 8.00 which is in accordance with model result which ranges from 3.35-16.64 and also the colour difference of akara egbe $19.99 \pm 0.3$ gotten from the control (100\% cowpea) has higher value as reported by [10]. At linear level, quadratic level and interaction between independent variables all had positive effect on the colour as shown in equation 8 .

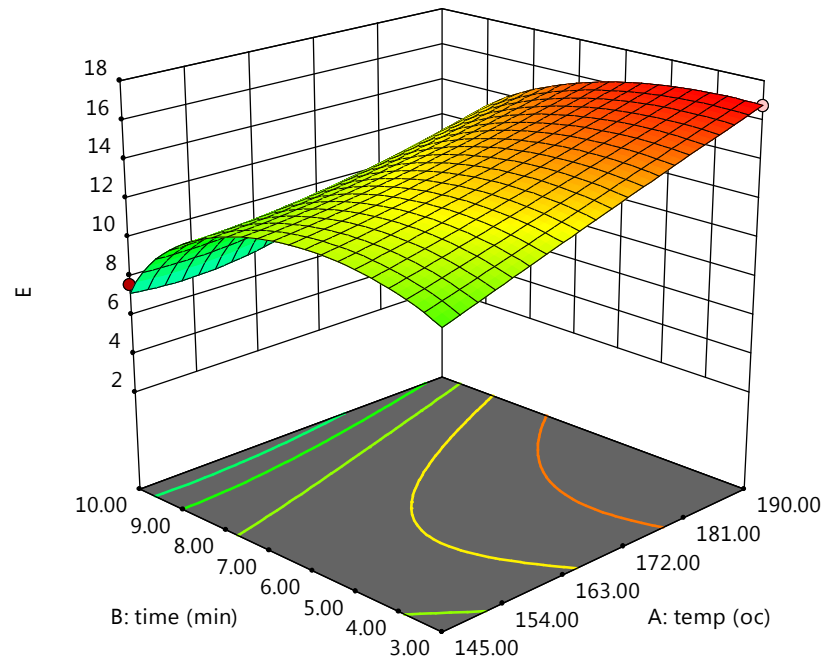

(a)

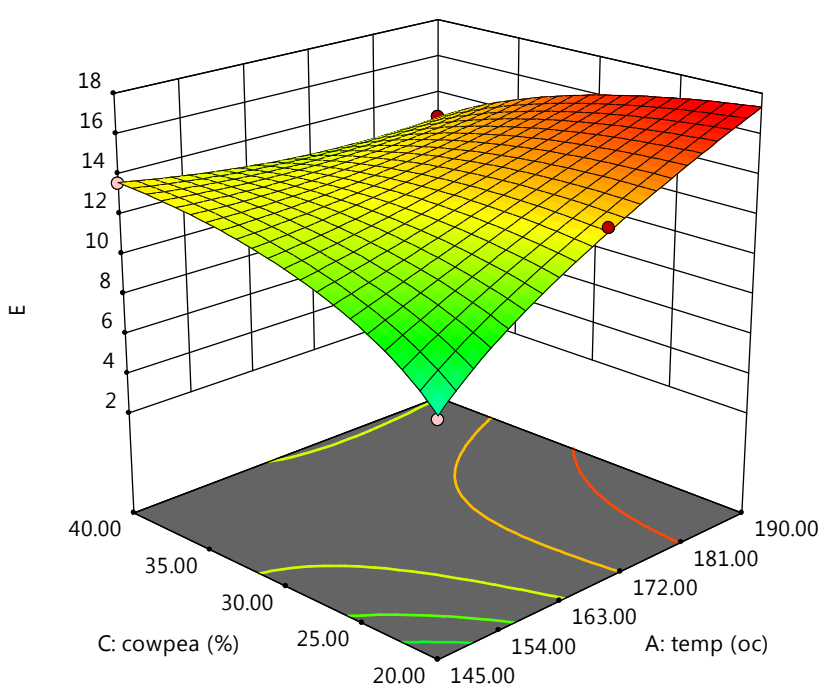

(b)

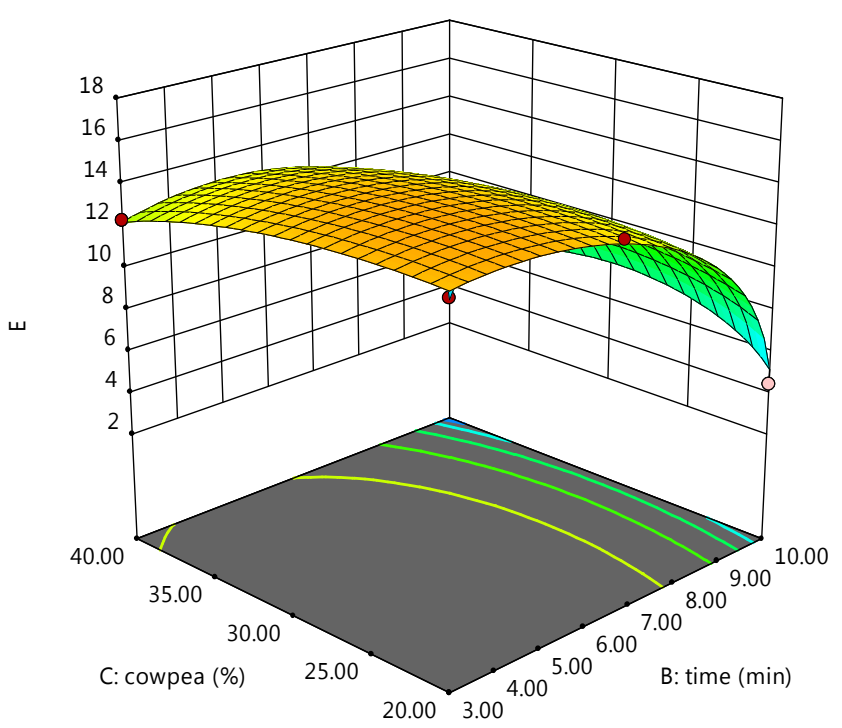

(c)

Figure 4. The surface plot for colour difference of deep fried akara egbe as affected by frying temperature, frying time and\%Bambara groundnut.

\subsection{Optimization of Parameters}

The optimum conditions obtained was a frying temperature of $190^{\circ} \mathrm{C}$, frying time $8.5 \mathrm{~min}$ and $20 \%$ bambara groundnut in the flour blend, having a desirability of 0.886 which lies between 0 and 1; and it represents the closeness of a response to its ideal value which gave moisture content of $4.84 \%, 9.76 \%$ oil content, $343.812 \mathrm{~N}$ crispness and 15.433 colour.

\section{Conclusion}

Akara egbe was produced by substituting cowpea with bambara groundnut. The study has shown that optimum conditions for processing akara egbe was at frying temperature of $190^{\circ} \mathrm{C}$, frying time $8.5 \mathrm{~min}$ and $20 \%$ Bambara groundnut which gave moisture content of $4.84 \%, 9.76 \%$ oil content, $343.81 \mathrm{~N}$ breaking force and 15.43 colour. 
The study also revealed that moisture content and colour difference decreased with increased in temperature and time and decreased in $\%$ Bambara groundnut substitution, oil content increased with increased in temperature and time and decreased in $\%$ Bambara groundnut substitution and crispness increased with decreased in moisture content and \% Bambara groundnut substitution. Moisture content, oil content and colour difference has minimum values, Crispness has higher values compared with past research work. Hence, the potentials of bambara groundnut can be harnessed industrially to reduce overdependence on cowpea.

\section{References}

[1] IITA (2007). Cowpea. IITA annual report.

[2] FAO. (2000). FAOSTAT Agricultural Data: Cowpeas, Dry Production. Rome: Food \& Agricultural Organization of the United Nations.

www.fao.org/page/collections?subset=agriculture.

[3] Abu-Salam, F. M., and Abuo-Arab, A. A. (2011). Effect of supplementation of Bambara groundnut (Vignasubterranean) flour on the quality of biscuits. African Journal Food Science, 5 (7): 376-383.

[4] Hillocks, R. J., Bennett, C., and Mponda, O. M. (2012). Bambara nut: A review of utilization, market potential and crop improvement. African Crop Science Journal 20: 1-16.

[5] Bamshaiye, O. M., Adegbola, J. A., and Bamishaiye, E. I. (2011). Bambara groundnut: An under-utilized nut in Africa. Advance Agricultural Biotechnology1: 60-72.

[6] Falade, K. O., Adedeji, A. A., and Akingbala, J. O. (2003). Effect of soybean substitution for cowpeaon physical, compositional, sensory and sorption properties of akaraOgbomoso. European Journal of Food Research and Technology217: 492-497.

[7] Olanipekun, B. F., Otunola, E. T., and Oyelade, O. J. (2015). Effect of fermentation on antrinutritional factors and invitro protein digestabilty of bambara nut (Voandzei Subterranean). Journal of Food science and management, 39: 98-110.
[8] Vitrac O., and Bohouon P. H. (2004). Internal coupled heat and mass transfer during deep-fat frying of materials withhigh water contents: application to apple chips fried at atmospheric pressure. In: International conferences Engineering and food, Montpellier, Pp 1-6.

[9] Adeyanju, J. A., Olajide, J. O., and Adedeji, A. A. (2016). Development of optimum operating conditions for quality attributes in Deep fat frying of Dodo from plantain using RSM. Food and Nutrition Sciences 7, 1423-1433. http://dx.doi.org/10.4236/fns.2016.714129.

[10] Sobukola, O. P., Awonorin, S. O., Sanni, L. O., and Bamiro, F. O. (2008). Deep fat frying of yam slices: Optimization of processing conditions using response surface methodology. Journal of Food Processing and Preservation, 32: 343-360.

[11] Sulaeman, A., Keeler, L., Giraud, D. W., Taylor, S. L., and Driskell J. A. (2001). Carotenoid content and physicochemical and sensory characteristics of carrot chips deep-fried in different oils at several temperatures. Journal of food science, 66: $1257-1264$.

[12] Agbaje L., Davies, T. E., Adelekan, A., Adelere, I. A., Adedeji, A. A., and Fadahunsi, A. H. (2010). Microbiological examination and identification of hazards and critical control points of akaraogbomoso. Food Science And Technology International 16: 389-403.

[13] AOAC. (2005). Official methods of chemical analysis. $5^{\text {th }}$ edition of American oil chemist's society chamaign, Illinois, Washington DC.

[14] Idowu, A. O., and O. C. Aworh. 2014. Optimization of some processing conditions for Kokoro production using Response Surface Methodology. Agric Eng Int: CIGR Journal, 16 (2): 187-195.

[15] Moreira, R. G., Sun, X., and Chen, Y. (1997). Factors affecting oil uptake in tortilla chips in deep-fat frying. Journal of Food Engineering, 31 (4): 485-498.

[16] Nantawan T, Phaisan W, Anuvat J, Chatlada K (2007) Optimisation of vacuum frying condition for shallot. Kas $J$ NaturSci 41: 338-342. 